\title{
Occurrence of the parasitoid Seminota marginata (Westwood, 1874) (Hymenoptera: Trigonalidae) in a nest of the social wasp, Apoica (Apoica) flavissima (Van der Vecht, 1973) (Hymenoptera: Vespidae)
}

\author{
Trindade, OSN. ${ }^{a *}$, Azevedo, GG. ${ }^{b}$, Smith, DR. ${ }^{c}$ and Silva-Júnior, JC. ${ }^{a}$ \\ ${ }^{a}$ Departamento de Ciências Biológicas, Universidade Estadual do Sudoeste da Bahia - UESB, \\ Av. José Moreira Sobrinho, s/n, Jequiezinho, CEP 45206-190, Jequié, BA, Brazil \\ 'bepartamento de Biologia, Centro de Ciências Biológicas e da Saúde, Universidade Federal do Maranhão - UFMA, \\ Av. dos Portugueses, s/n, CEP 65085-580, São Luis, MA, Brasil \\ ${ }^{c}$ Department of Entomology, National Museum of Natural History, Smithsonian Institution, \\ Washington, D.C. 20013-7012, USA \\ *e-mail: ozzybiologo@yahoo.com.br
}

Received November 25, 2011 - Accepted February 15, 2012 - Distributed November 30, 2012

The family Trigonalidae is a small group of cosmopolitan, but poorly studied parasitoid wasps. Nearly 100 species in 16 genera have been described. Their body size ranges from 5 to $15 \mathrm{~mm}$ in length, although some species are as small as $3 \mathrm{~mm}$ (Carmean and Kimsey, 1998). Most species collected in the Americas are hyperparasitoids of Ichneumonidae and Tachinidae that parasitize Lepidoptera or of social wasps (Weinstein and Austin, 1991; Smith, 1996). Some species have been recorded as primary parasitoids of sawflies (Hymenoptera: Pergidae) in Australia (Weinstein and Austin, 1995).

The genus Seminota Spinola, 1840 includes six species in the Neotropical Region (Carmean, 2006), two of which have been reported from Brazil, S. marginata (Westwood, 1874) and S. depressa (De Geer, 1773) (Carmean and Kimsey, 1998). Weinstein and Austin (1991) summarized the association between Seminota species and social wasps of the genera Polistes Latreille, 1802; Apoica Lepeletier, 1836; Pseudopolybia Dalla Torre, 1894 and Parachartegus Inhering, 1904. Bertoni (1912) was the first to report the association between the parasitoid S. marginata and larvae of the following social wasp species: Polistes versicolor (Olivier, 1791), P. cinerascens (Saussure, 1857), P. melanossoma (Saussure, 1853), P. canadensis (Linnaeus, 1758) and Apoica pallida (Olivier, 1791). For the first time, we report the association of $S$. marginata with Apoica (Apoica) flavissima (Van der Vecht, 1973).

A colony of Apoica (A.) flavissima was collected in the caatinga (dry bushwood), Brejões municipality, Bahia, Brazil (S 13 04' 18.6" and W 39 $47^{\circ}$ '02.2") on July $29^{\text {th }}$ 2010. The material was transported and kept in the laboratory in plastic trays covered with a thin organza fabric. On August $1^{\text {st }} 2010$, four specimens of $S$. marginata emerged from the nest. The specimens were approximately $14 \mathrm{~mm}$ long, with black bodies, partially dark wings, and smooth, shiny heads. The specimens were identified by David R. Smith and are deposited in the entomology collections of the Insect Biology Laboratory at Universidade Estadual do Sudoeste da Bahia, Bahia, Brazil and at the National Museum of Natural History, Smithsonian Institution, Washington, D.C., USA.

The life cycle of trigonalids is complex. Females usually lay a large number of tiny eggs on leaf surfaces. To initiate their development, these eggs need to be ingested by larvae of phytophagous insects, mainly lepidopterans. Most likely, when social wasps catch infected caterpillars and take them to their nest to feed their immatures, the caterpillar with the trigonalid larvae are ingested by the wasp larvae. The trigonalid endoparasitoid then feeds on the immature wasp, which represents its definitive host (Carmean, 1991; Smith, 1996).

Acknowledgements - We would like to thank the biologist, David Barros Muniz, UFMA (Universidade Federal do Maranhão) for his assistance in identifying the parasitoid family and Paulo Roberto Antunes de Mello Affonso for proofreading the text in English.

\section{References}

BERTONI, AW., 1912. Contribucion a la biologia de las avispas y abejas del Paraguay (Hymenoptera). Anales del Museo Nacional de Historia Natural de Buenos Aires, vol. 22, no. 1, p. 97-146.

CARMEAN, D., 1991. Biology of the Trigonalyidae (Hymenoptera), with notes on the vespine parasitoid Bareogonalos canadensis. New Zealand Journal of Zoology, vol. 18, no. 1, p. 209-214.

-, 2006. Superfamilia Trigonalioidea y família Trigonalidae. In FERNÁNDEZ, F. and SHARKEY, MJ. (Eds.). Introducción a los Hymenoptera de la Región Neotropical. Bogotá: Universidad Nacional de Colombia. p. 647-660.

CARMEAN, D. and KIMSEY, L., 1998. Phylogenetic revision of the parasitoid wasp family Trigonalidae (Hymenoptera). Systematic Entomology, vol. 23, no. 1, p. 35-76. http://dx.doi. org/10.1046/j.1365-3113.1998.00042.x 
Trindade, OSN. et al.

SMITH, DR., 1996. Trigonalyidae (Hymenoptera) in the eastern United States: seasonal flight activity, distributions, hosts. Proceedings of the Entomological Society of Washington, vol. 98, no. 1, p. 109-118.

WEINSTEIN, P. and AUSTIN AD., 1991. The host-relationships of Trigonalyid wasps (Hymenoptera: Trigonalyidae), with a review of their biology and catalogue to world species. Journal of Natural History, vol. 25, no. 1, p. 399-433. http://dx.doi. org/10.1080/00222939100770281

-, 1995. Primary parasitism, development and adult biology in the wasp Taeniogonalos venatoria Riek (Hymenoptera: Trigonalyidae). Australian Journal of Zoology, vol. 43, no. 1, p. 541-555. 